\title{
Analiza wpływu długości otworu kierunkowego na ekonomiczną opłacalność eksploatacji mioceńskich formacji łupkowo-mułowcowych
}

\begin{abstract}
W Polsce w latach 2010-2015 trwały intensywne prace wiertniczo-poszukiwawcze skoncentrowane na utworach ilastych paleozoiku (ordowik, sylur) mające na celu odkrycie i podjęcie opłacalnej eksploatacji gazu z formacji łupkowych. Niestety ich rezultaty nie były pozytywne. Autorzy niniejszej pracy, kierując się genezą rozwoju eksploatacji warstw łupkowych w USA, doszli do wniosku, że mioceńskie skały łupkowo-mułowcowe również spełniają kryteria złóż niekonwencjonalnych. W związku z tym, począwszy od 2010 roku, prowadzili szereg badań pod kątem ekonomicznie opłacalnej możliwości eksploatacji niekonwencjonalnych złóż gazu ziemnego występujących w warstwach mioceńskich. Głównym celem artykułu jest wykazanie wpływu konstrukcji odwiertu udostępniającego niekonwencjonalne złoża mioceńskie na efektywność ekonomiczną inwestycji. Analiza została wykonana z wykorzystaniem cyfrowego modelu symulacyjnego przykładowego złoża mioceńskiego. Poszczególne odwierty miały ten sam punkt wejścia w horyzont, a różniły się tylko długością odcinka udostępnienia złoża, wynikającą z wiercenia odwiertów coraz bardziej odchylonych od pionu. Porównanie efektywności ekonomicznej wiercenia odwiertów poziomych/kierunkowych o różnej długości odcinków „poziomych” wykonano, opierając się na analizie finansowej, której podstawą był wskaźnik NPV.
\end{abstract}

Słowa kluczowe: miocen, złoża niekonwencjonalne, odwierty kierunkowe, wydajność odwiertów.

\section{The impact of the directional well length on the economic viability of gas production from Miocene shale-mudstone strata}

\begin{abstract}
In Poland in the years 2010-2015, intensive drilling and exploration work was focused on the Paleozoic shale rocks (Ordovician, Silurian), and was aimed at the discovery and cost-effective gas production. Unfortunately, no positive results were obtained. The authors of this study, following the genesis of the development of operational layers of shale in the US, came to the conclusion that the Miocene shale mudstone rocks also meet the criteria for unconventional deposits. Therefore, starting from 2010, they conducted a series of studies for economically viable opportunities for the exploitation of unconventional natural gas occurring in the Miocene strata. The main aim of this article, is to demonstrate the impact of the well completion for unconventional Miocene reserves on the economic effectiveness of the investment. The analysis was performed based on a digital simulation model of the Miocene unconventional deposits. Individual wells had the same entry point horizontally but different lengths of the pay zone resulting from the drilling of wells, increasingly inclined from the vertical. A comparison of the economic efficiency of drilling horizontal/directional wells of varying lengths was made on the basis of the NPV financial indicator.
\end{abstract}

Key words: miocene, unconventional gas fields, directional wells, well production.

Aktualnie większość polskich konwencjonalnych złóż gazu ziemnego charakteryzuje się wysokim stopniem sczerpania zasobów. Począwszy od 2000 roku, praktycznie nie odkryto nowych znaczących złóż gazu ziemnego zlokalizowanych w Polsce południowo-wschodniej. Jedynym wyjątkiem jest złoże gazu ziemnego Siedleczka. Negatywne wyniki poszukiwań uzyskane podczas ostatnich lat wskazują, że odkrycie tradycyjnych złóż gazu ziemnego staje się coraz trudniejsze i wymaga zaangażowania coraz większych środków. W tej sytuacji w Polsce powoli rysuje się nowy trend, który polega 
na poszukiwaniu niekonwencjonalnych złóż gazu ziemnego. W latach 2010-2015 trwały intensywne prace wiertniczo-poszukiwawcze skoncentrowane na utworach ilastych paleozoiku (ordowik, sylur) mające na celu odkrycie i podjęcie opłacalnej eksploatacji gazu z formacji łupkowych [4]. Niestety dotychczasowe prace nie przyniosły pozytywnych rezultatów. Nie udało się uzyskać przemysłowego przypływu gazu z żadnego wykonanego odwiertu. Autorzy niniejszej pracy, kierując się genezą rozwoju eksploatacji warstw łupkowych w USA, doszli do wniosku, że pojęcie gazu eksploatowanego z warstw typu shale w USA i Kanadzie stosowane jest w sposób bardzo szeroki. Jedna z najpełniejszych definicji shale gazu została przedstawiona w opracowaniu What is shale gas? An introduction to shale-gas geology in Alberta [5].

W publikacji tej wykazano, że termin shale gas jest używany w sposób luźny i w zamierzeniu nie opisuje litologii złoża. Litologiczna zmienność w amerykańskich złożach typu shale gas wskazuje, że gaz ziemny znajduje się nie tylko w łupkach, ale również w szerokim spektrum skał o zróżnicowanej litologii i teksturze, od mułowców do bardzo drobnoziarnistych piaskowców. Autorzy niniejszego artykułu, czytając powyższą definicję w 2010 roku, odnieśli wrażenie, że opisuje ona skałę gazonośną mioceńskich złóż zlokalizowanych w Polsce południowo-wschodniej. W związku z tym, począwszy od 2010 roku, zajęli się analizą możliwości eksploatacji niekonwencjonalnych złóż gazu ziemnego występujących w lupkowo-mułowcowych utworach miocenu. Głównym celem artykułu jest wykazanie wpływu sposobu udostępnienia mioceńskich niekonwencjonalnych złóż gazu ziemnego na efektywność ekonomiczną inwestycji. Eksploatacja złóż niekonwencjonalnych bazuje na dwóch technologiach rozwiniętych w ostatnich czasach:

- technologii wiercenia otworów horyzontalnych,

- technologii szczelinowania hydraulicznego.

Początkowo odwierty horyzontalne były wykorzystywane do eksploatacji złóż o małej miąższości i niskiej przepuszczalności oraz skał posiadających naturalną siatkę szczelin (spękań). Aktualnie odwierty horyzontalne są podstawą w eksploatacji niekonwencjonalnych złóż ropy naftowej i gazu ziemnego. Drugą technologię, bez której nie jest możliwa eksploatacja złóż typu shale gas, stanowi szczelinowanie hydrauliczne w odwiertach horyzontalnych [3].

Należy podkreślić, że utwory mioceńskie charakteryzują się odmiennymi parametrami niż typowe skały łupkowe złóż amerykańskich. Podczas gdy gaz ziemny w skałach typu shale znajduje się w porach pozostałych po przeobrażonym w metan detrytusie roślinnym, to w miocenie zapadliska przedkarpackiego występuje on przede wszystkim w porach międzyziarnowych lamin mułowcowych. W miocenie migracja gazu ze skały do odwiertu odbywa się z wykorzystaniem lamin mu- łowcowych. Tymczasem w klasycznych łupkach przemieszczanie gazu do odwiertu jest możliwe jedynie przez sieć naturalnych spękań występujących w skale macierzystej lub poprzez szczeliny wytworzone sztucznie. W związku z tym jedynym sposobem eksploatacji klasycznych złóż gazu typu shale jest zastosowanie odwiertów horyzontalnych wraz z zabiegami wielosekcyjnego szczelinowania.

Dodatkową istotną różnicą pomiędzy skałami typu shale a skałami łupkowo-mułowcowymi miocenu jest stosunkowo duża zawartość minerałów pęczniejących w skałach.

Wydaje się, że ta cecha daje podstawę do stwierdzenia, że efektywność szczelinowania hydraulicznego skał łupkowo-mułowcowych miocenu może być niższa niż analogicznego szczelinowania wykonanego w skałach typu shale. Należy podkreślić, że jest to tylko hipoteza, dotychczas niepotwierdzona danymi rzeczywistymi ze względu na brak przemysłowych zabiegów szczelinowania wykonanych w warstwach mioceńskich. Z drugiej strony należy pamiętać, że przepuszczalność niekonwencjonalnych skał miocenu jest dużo wyższa $(0,5 \div 0,01 \mathrm{mD})$ niż ,typowych” skał łupkowych $(100 \div 500 \mathrm{nD})$. Przedstawione powyżej różnice skłaniają do tego, aby przynajmniej w początkowej fazie rozpoznania/eksploatacji niekonwencjonalnych złóż gazu ziemnego występujących w osadach łupkowo-mułowcowych miocenu zastosować technologię otworów horyzontalnych, bez zabiegów szczelinowania. Odwierty horyzontalne projektowane w celu udostępnienia mioceńskich złóż niekonwencjonalnych powinny zostać wykonane bez cementowania odcinka poziomego, w systemie open hole. Głównym celem tego rozwiązania będzie uzyskanie dopływu gazu na całym odcinku poziomym, ze wszystkich wkładek mułowcowych. To podejście w maksymalny możliwy sposób wykorzystuje naturalne własności łupkowo-mułowcowych skał zbiornikowych, które zbudowane są z łupków z cienkimi (od ułamka milimetra do kilku centymetrów) wkładkami mułowców, sporadycznie drobnoziarnistych piaskowców.

Należy pamiętać, że część niekonwencjonalnych złóż mioceńskich jest zlokalizowana w bezpośredniej bliskości terenów zamieszkałych/zabudowanych, w związku z tym będzie trudno uzyskać zgodę ludności lokalnej na wykonanie zabiegów szczelinowania.

Skały zbiornikowe złóż niekonwencjonalnych Polski południowo-wschodniej zbudowane są z matrycy łupkowej zawierającej cienkie, milimetrowe lub kilkucentymetrowe, wkładki mułowców. Pomimo tego, że miąższość tych serii dochodzi do kilkuset metrów, otwory pionowe mają stosunkowo niską wydajność, gdyż średnia wartość przepuszczalności jest poniżej $0,5 \mathrm{mD}$. Początkowe absolutne wydajności odwiertów pionowych eksploatujących horyzonty łupkowo-mułowcowe gazu ziemnego są niskie i osiągają od kilku- 
nastu do $30 \mathrm{~m}^{3} / \mathrm{min}$. Podstawę każdej inwestycji stanowi jej opłacalność, która w przypadku eksploatacji jest ściśle skorelowana $\mathrm{z}$ wydajnością odwiertu. Zwiększenie wydajności projektowanego odwiertu można uzyskać poprzez wykonanie otworu poziomego, o jak najdłuższym odcinku ,poziomym" [1]. Drugim istotnym problemem, przed którym stoi inwestor pragnący rozpocząć eksploatację złóż niekonwencjonalnych, jest minimalizacja kosztu wiercenia pierwszego odwiertu horyzontalnego. S. Joshi wykazał, że koszty wiercenia na danym złożu odwiertów horyzontalnych maleją wraz z liczbą wykonanych odwiertów [2]. Zależność ta została nazwana krzywą zdobywania doświadczenia. Zgodnie $\mathrm{z}$ danymi przedstawionymi przez Joshiego koszt wiercenia odwiertu horyzontalnego znacząco spada, gdy na danym złożu wykonuje się więcej niż 5 odwiertów poziomych. Koszt odwiertu poziomego może zmniejszyć się z 2,5-krotności kosztu odwiertu pionowego do około 1,3. Dodatkową zaletą zastosowania odwiertów poziomych jest możliwość wiercenia kilku odwiertów z jednej platformy wiertniczej, co w znaczącym stopniu zmniejsza fizyczny obszar potrzebny do zagospodarowania złóż niekonwencjonalnych, a co za tym idzie - koszty.

W celu pokazania wpływu sposobu udostępnienia złoża na wielkość wydobycia z niego gazu autorzy pracy zdecydowali się na wykonanie analizy porównawczej, wykorzystując cyfrowy model symulacyjny przykładowego złoża. Konstrukcja każdego odwiertu była identyczna i polegała na udostępnieniu całego interwału złoża rurami traconymi o średnicy 7", ciętymi na powierzchni. Poszczególne odwierty miały ten sam punkt wejścia w horyzont, a różniły się tylko długością odcinka udostępnienia złoża, wynikającą z wiercenia odwiertów coraz bardziej odchylonych od pionu. Porównanie efektywności ekonomicznej wiercenia odwiertów poziomych/kierunkowych o różnej długości odcinków „poziomych” wykonano, opierając się na analizie finansowej, która wykorzystała wskaźnik NPV.

\section{Budowa cyfrowego modelu symulacyjnego}

Analiza została wykonana na podstawie symulacji przeprowadzonych z wykorzystaniem oprogramowania firmy Computer Modelling Group (IMEX, Builder, Results). Przestrzenna budowa modelu symulacyjnego została oparta na typowych parametrach niekonwencjonalnych złóż łupkowo-mułowcowych. Model symulacyjny posiada siatkę bloków symulacyjnych o rozmiarze $50 \times 100 \times 10$. Powierzchnia złoża została podzielona siatką o szerokości 50 bloków i długości 100 bloków. Każdy blok ma rozmiar $100 \times 100 \mathrm{~m}$. Model symulacyjny posiada również 10 warstw symulacyjnych, każda o miąższości $30 \mathrm{~m}$. Ogółem model składa się z 50000 bloków. Obraz przekroju podłużnego wykonanego przez projektowany odwiert kierunkowy prezentuje rysunek 1 . W celu zniwelowania wpływu lokalizacji odwiertu na jego wydajność postanowiono przyjąć założenie, że każda warstwa symulacyjna będzie posiadać takie same wielkości parametrów na całej powierzchni. Podstawowe parametry petrofizyczne zostały określone w następujący sposób:

- miąższość każdego bloku wynosi $30 \mathrm{~m}$,

- porowatość każdego bloku wynosi 4\%,

- przepuszczalność pozioma każdego bloku wynosi 0,1 mD,

- przepuszczalność pionowa każdego bloku wynosi 0,01 mD,

- zapiaszczenie: $25 \%$.

Pozostałe parametry modelu zostały przyjęte w następujący sposób:

- pierwotne ciśnienie złożowe: $13 \mathrm{MPa}$,

- pierwotne nasycenie gazem: $70 \%$,

- gęstość względna gazu $S g=0,56$,

- stała depresja ciśnienia odbioru gazu $d p=3 \mathrm{MPa}$,
- ciśnienie odbioru wyższe niż 1,5 MPa,

- kontakt gaz-woda: $1300 \mathrm{~m}$.

Analiza wpływu konstrukcji odwiertu na wydobycie gazu ze złoża została przeprowadzona dla 4 różnych odwiertów, wierconych $\mathrm{z}$ odchyleniem od pionu wynoszącym od $0^{\circ}$ (odwiert pionowy) do $75^{\circ}$. Każdy odwiert miał taką samą średnicę końcową ( $\left(7^{\prime \prime}\right)$ oraz identyczne rury wydobywcze $\left(2^{3} / 8^{\prime \prime}\right)$. Założono również, że każdy odwiert będzie udostępniał całą miąższość złoża $300 \mathrm{~m}$. W przypadku wszystkich odwiertów wykonano symulację eksploatacji w okresie 20 lat, począwszy od roku 2010. Przeprowadzone symulacje na przykładowym złożu niekonwencjonalnym pokazały, że istnieje duży wpływ sposobu udostępnienia złoża na sumaryczne wydobycie gazu z odwiertu (tablica 1 ).

Tablica 1. Zestawienie wyników symulacji

\begin{tabular}{|c|c|c|c|}
\hline $\begin{array}{c}\text { Kąt odchylenia } \\
\text { odwiertu od pionu } \\
{\left[{ }^{\circ}\right]}\end{array}$ & $\begin{array}{c}\text { Otwarcie } \\
{[\mathrm{m}]}\end{array}$ & $\begin{array}{c}\text { Wydajność } \\
\text { początkowa } \\
{\left[\text { tys. } \mathrm{m}^{3} / \mathrm{d}\right]}\end{array}$ & $\begin{array}{c}\text { Wydobycie } \\
\text { po 20 latach } \\
{\left[\mathrm{mln} \mathrm{m}^{3}\right]}\end{array}$ \\
\hline $\mathrm{W}-0^{\circ}$ & 300 & 13,3 & 86,0 \\
\hline $\mathrm{W}-58^{\circ}$ & 569 & 20,4 & 123,3 \\
\hline $\mathrm{W}-68^{\circ}$ & 838 & 28,5 & 173,8 \\
\hline $\mathrm{W}-75^{\circ}$ & 1162 & 37,8 & 220,1 \\
\hline
\end{tabular}

Wyniki symulacji pokazują, że sposób udostępnienia złoża ma wpływ na oczekiwaną wydajność projektowanego odwiertu (rysunek 2). Symulacje wykazały, że jedyną możliwością znaczącego zwiększenia oczekiwanego wydobycia z odwiertu jest wykonanie odwiertu horyzontalnego o stosunkowo 
długim odcinku udostępnienia złoża. Symulacje dowiodły również, że sumaryczne wydobycie gazu z odwiertu kierunkowego (o kącie $75^{\circ}$ ) jest wyższe o około $156 \%$ od wydobycia gazu z odwiertu pionowego (rysunek 3 ).

Należy pamiętać o tym, że prognoza wydobycia gazu z odwiertu pionowego jest wiarygodna, gdyż została poparta kalibracją modelu przeprowadzoną z wykorzystaniem danych rzeczywistych. Niestety obecnie nie ma danych pochodzących z eksploatacji złóż niekonwencjonalnych występujących w warstwach łupkowo-mułowcowych z wykorzystaniem odwiertów o większym odchyleniu od pionu niż $34^{\circ}$. W związku z tym wyniki symulacji należy traktować jako szacunkowe, gdyż każdy model symulacyjny powinien zostać skalibrowany na podstawie danych rzeczywistych.

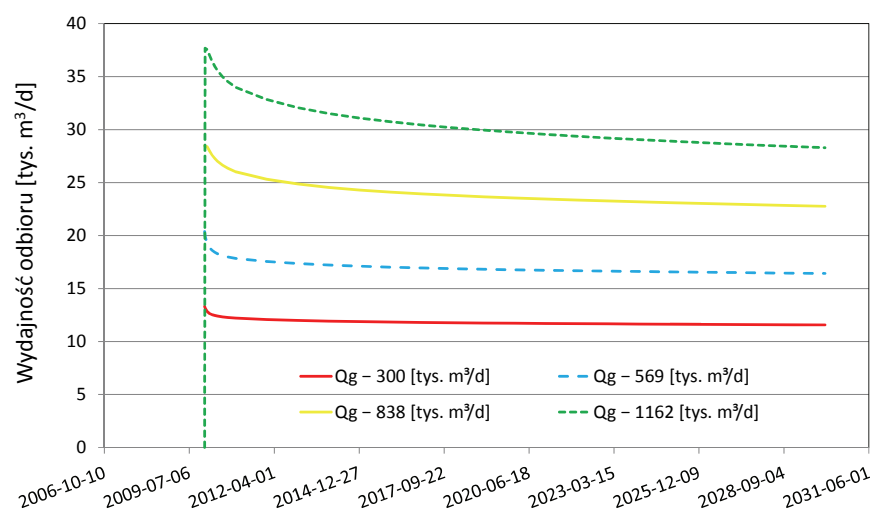

Rys. 2. Wykres wydajności odwiertów o różnym odcinku udostępnienia złoża

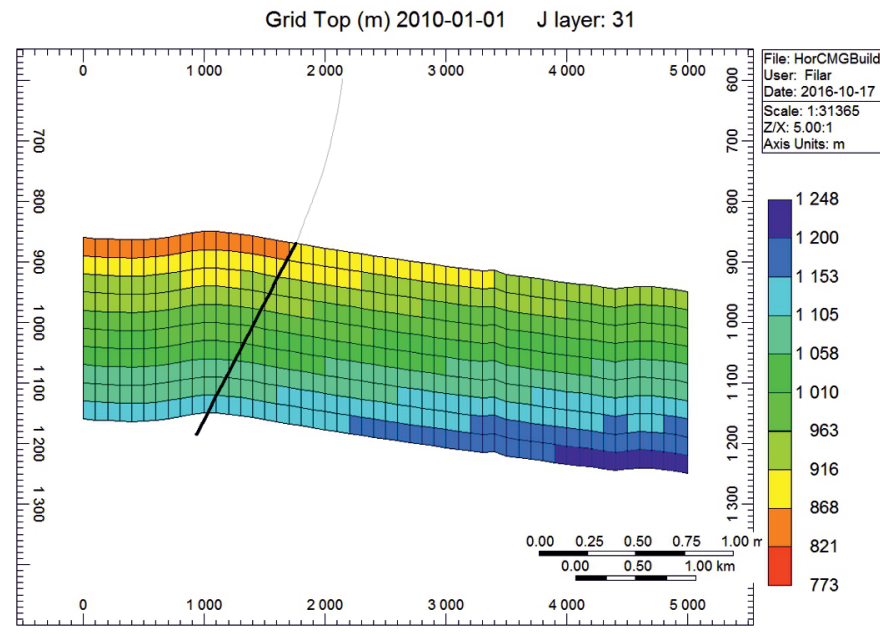

Rys. 1. Przekrój poprzeczny przez przykładowe złoże

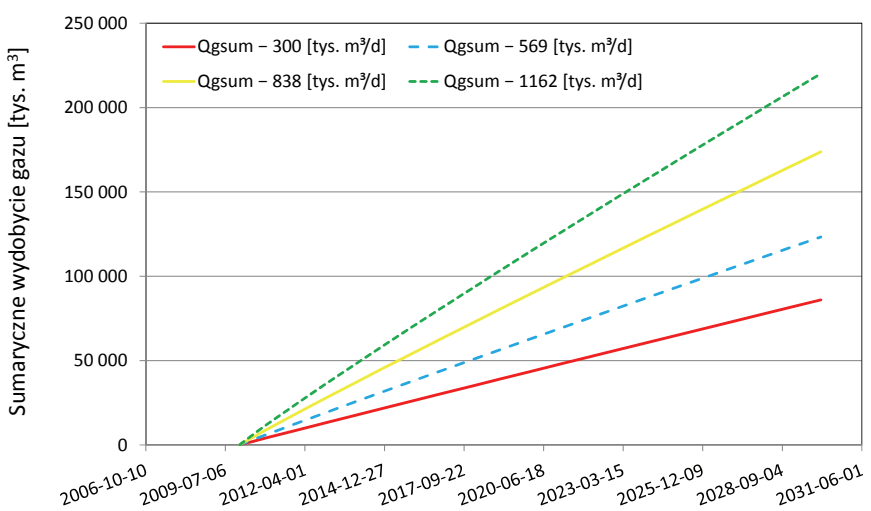

Rys. 3. Wykres sumarycznego wydobycia gazu z odwiertów o różnym odcinku udostępnienia złoża

\section{Szacunkowa analiza ekonomicznej opłacalności zastosowania odwiertów kierunkowych do eksploatacji niekonwencjonalnych złóż występujących w warstwach łupkowo-mułowcowych}

Wykonanie szacunkowej analizy finansowej inwestycji, która wykorzystuje inną technologię niż dotychczas stosowana, jest trudne ze względu na brak precyzyjnych danych dotyczących kosztów i wielkości wydobycia gazu. Autorzy opracowania pomimo braku dokładnych kosztów oraz wielkości wydobycia zdecydowali się na wykonanie finansowej analizy porównawczej, gdyż tylko ona może odpowiedzieć na pytanie, czy stosowanie konkretnej technologii ma sens ekonomiczny. Wiercenie otworów horyzontalnych z jednej strony generuje większe koszty niż wykonanie otworów pionowych, z drugiej strony wpływa na wyższe wydobycie gazu ze złoża. Szacunkowa analiza finansowa została przygotowana dla różnych konstrukcji otworu udostępniającego przykładowe złoże występujące w warstwach łupkowo-mułowcowych. Analizę finansową wykonano dla 4 odwiertów o różnym odchyleniu od pionu (tablica 1):

- odwiert pionowy, odcinek udostęniający złoże: 300 m, - odwiert kierunkowy, odcinek udostępniający złoże: 569 m, - odwiert kierunkowy, odcinek udostępniający złoże: 838 m,
- odwiert kierunkowy, odcinek udostępniający złoże: $1162 \mathrm{~m}$.

Wyniki symulacji wydobycia gazu z odwiertów przedstawiono w tablicy 1 . Rysunek 3 prezentuje sumaryczne wydobycie z każdego odwiertu. Wydobycie z poszczególnych odwiertów uzyskane z symulacji było bezpośrednio wzięte do modelu finansowego.

\section{Założenia przyjęte do wykonania analizy finansowej}

1. Obliczenia były prowadzone w cenach nominalnych.

2. Nominalna stopa dyskontowa wynosi $12,5 \%$ (realna: $10 \%$ ).

3. Założono prognozowaną stopę inflacji w wysokości $2,5 \%$ rocznie.

4. Do analizy przyjęto również szacunkową cenę gazu w pierwszym roku (roku rozpoczęcia inwestycji) wynoszącą $1000 \mathrm{zł} /$ tys. $\mathrm{m}^{3} \mathrm{i}$ stopę wzrostu ceny $2,5 \%$ rocznie (według stopy inflacji).

5. Założono również, że odwiert zostanie odwiercony w pierwszym roku inwestycji, podłączony do eksploata- 
cji w drugim, a eksploatacja rozpocznie się od 1 stycznia trzeciego roku.

6. Okres eksploatacji odwiertu wynosi 20 lat.

\section{Nakłady inwestycyjne}

Nakłady inwestycyjne określono szacunkowo na podstawie dostępnych danych (tablica 2).

Tablica 2. Zestawienie szacunkowych kosztów odwiertów

\begin{tabular}{|c|c|c|}
\hline Typ odwiertu & $\begin{array}{c}\text { Koszt odwiercenia }+ \\
\text { wyposażenie } \\
\text { [tys. zł] }\end{array}$ & $\begin{array}{c}\text { Koszt podłączenia } \\
\text { [tys. zł] }\end{array}$ \\
\hline $\mathrm{W}-0^{\circ}$ & 7700,0 & 1000 \\
\hline $\mathrm{W}-58^{\circ}$ & 10450,0 & 1000 \\
\hline $\mathrm{W}-68^{\circ}$ & 13080,0 & 1000 \\
\hline $\mathrm{W}-75^{\circ}$ & 16320,0 & 1000 \\
\hline
\end{tabular}

\section{Przychody}

Przychody roczne wynikają ze sprzedaży gazu wydobytego w poszczególnych latach; dane uzyskane podczas symulacji.

\section{Koszty}

Koszty eksploatacji zostały przyjęte w sposób przedstawiony w tablicy 3 , takie same dla wszystkich wariantów.

Tablica 3. Zestawienie kosztów eksploatacji

\begin{tabular}{|l|c|}
\hline \multicolumn{1}{|c|}{ Typ kosztu } & Koszt \\
\hline Stały [tys. zł/rok] & 500 \\
\hline Zmienny $\left[\mathrm{z} / 1000 \mathrm{~m}^{3}\right]$ & 20 \\
\hline Opłata eksploatacyjna $\left[\mathrm{z} \mathrm{l} / 1000 \mathrm{~m}^{3}\right]$ & 5,89 \\
\hline
\end{tabular}

\section{Wyniki szacunkowej analizy finansowej}

Wyniki szacunkowej analizy finansowej przedstawiono w tablicy 4.

Można zauważyć, jak należało przypuszczać, że odwiert pionowy jest najmniej opłacalny ekonomicznie ze wszystkich czterech wariantów. Jego szacunkowe NPV wynosi
10,9 mln zł, a NPV odwiertu kierunkowego o nachyleniu $75^{\circ}$ wynosi 41,9 mln zł. Rysunek 4 prezentuje wartość NPV obliczoną dla wszystkich czterech wariantów analizy finansowej w całym 20-letnim okresie eksploatacji przykładowego złoża. Przeprowadzone obliczenia wykazały, że inwestycja polegająca na odwierceniu odwiertu kierunkowego o długości udostępnienia złoża wynoszącej $1162 \mathrm{~m}\left(75^{\circ}\right)$ pozwoli na uzyskanie NPV w wielkości 41,9 mln zł, co stanowi 384\% wielkości NPV obliczonej dla odwiertu pionowego.

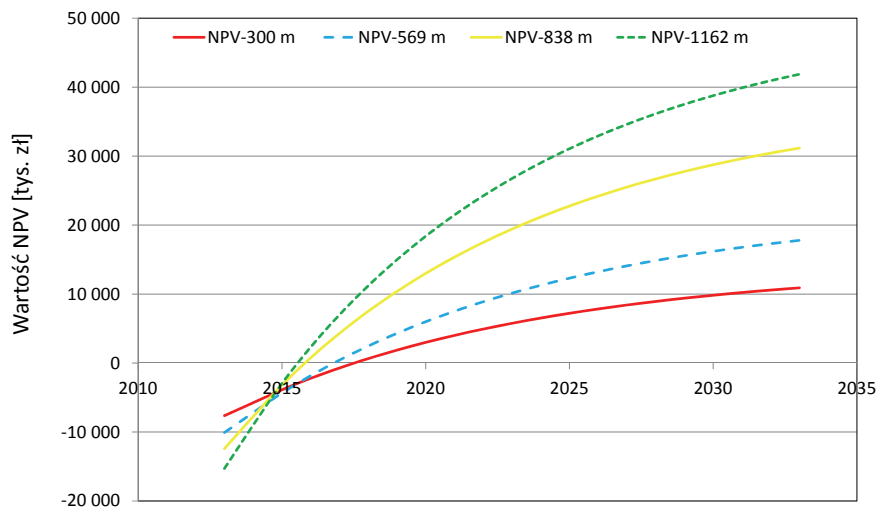

Rys. 4. Wykres zmiany wartości NPV obliczonej dla odwiertów o różnej długości udostępnienia złoża

Wykonana analiza finansowa ma charakter szacunkowy i jej głównym celem było wykazanie wpływu konstrukcji odwiertu na opłacalność eksploatacji złoża, a nie przygotowanie analizy dla rzeczywistego złoża. Wszystkie koszty zostały oszacowane na bazie dostępnych danych, natomiast przychody pochodzą z wydobycia gazu z przykładowego złoża o założonym ciśnieniu złożowym.

Należy podkreślić, że podobna analiza powinna zostać wykonana dla rzeczywistego złoża (nowego lub sczerpanego) w celu podjęcia decyzji inwestycyjnej. Tylko kompleksowa analiza złożowo-finansowa pozwoli na minimalizację ryzyka inwestycyjnego, gdyż istnieje ścisła zależność pomiędzy parametrami złoża, konstrukcją odwiertu, kosztami inwestycyjnymi i eksploatacyjnymi a oczekiwanym wynikiem finansowym. W związku z tym, że każde złoże jest inne, dla każdego potrzeba opracować optymalny wariant inwestycyjny.

Tablica 4. Zbiorcze zestawienie wyników analizy ekonomicznej

\begin{tabular}{|l|c|c|c|c|}
\hline \multicolumn{1}{|c|}{ Parametr } & $\begin{array}{c}\text { Wariant } \\
300 \mathrm{~m}\end{array}$ & $\begin{array}{c}\text { Wariant } \\
569 \mathrm{~m}\end{array}$ & $\begin{array}{c}\text { Wariant } \\
838 \mathrm{~m}\end{array}$ & $\begin{array}{c}\text { Wariant } \\
1162 \mathrm{~m}\end{array}$ \\
\hline Nakłady inwestycyjne [tys. zł] & 8700 & 11450 & 14080 & 17320 \\
\hline Cena gazu w pierwszym roku [zł/tys. m ${ }^{3}$ ] & 1000 & 1000 & 1000 & 1000 \\
\hline Stopa wzrostu ceny gazu [\%/rok] & $2,5 \%$ & $2,5 \%$ & $2,5 \%$ & $2,5 \%$ \\
\hline NPV [mln zł] & 10,9 & 17,8 & 31,2 & 41,9 \\
\hline
\end{tabular}




\section{Podsumowanie i wnioski}

W świetle przeprowadzonych analiz niekonwencjonalne mioceńskie złoża łupkowo-mułowcowe powinny zostać rozwiercane z wykorzystaniem technologii odwiertów kierunkowych/horyzontalnych. Długość odcinka „poziomego” udostępniającego złoże powinna zostać dobrana w taki sposób, aby oczekiwane wydobycie gazu było jak największe. Ponieważ wydłużanie odcinka udostępnienia złoża, poprzez zwiększanie kąta odchylenia odwiertu od pionu, prawdopodobnie wpłynie na problemy wiertnicze, a co za tym idzie - na koszty, to dla każdego złoża istnieje optymalny kąt odchylenia od pionu. Ze względu na brak informacji analiza finanso- wa wykonana w pracy zakładała, że wszystkie otwory o kącie od $0^{\circ}$ do $75^{\circ}$ będzie się wierciło równie łatwo. Wyniki pracy pozwalają na wyciągnięcie następujących wniosków:

- przeprowadzona analiza wykazała, że wydłużanie odcinka udostępniającego złoże niekonwencjonalne powinno pozytywnie wpłynąć na oczekiwany wynik finansowy,

- prawdopodobnie każde złoże ma optymalną ze względu na koszty wiercenia odwiertu długość odcinka ,poziomego" udostępniającego złoże,

- w związku z tym, że każde złoże jest inne, to podobna analiza powinna poprzedzić każdą planowaną inwestycję.

Prosimy cytować jako: Nafta-Gaz 2016, nr 12, s. 1107-1112, DOI: 10.18668/NG.2016.12.14

Artykuł nadesłano do Redakcji 25.10.2016 r. Zatwierdzono do druku 15.11.2016 r.

Artykuł powstał na podstawie pracy statutowej pt. Opracowanie algorytmu pozwalajacego na dobór optymalnej technologii udostępnienia mioceńskich niekonwencjonalnych złóż gazu ziemnego - praca INiG - PIB na zlecenie MNiSW; nr zlecenia 28/KP, nr archiwalny DK-4100-28/2016.

\section{Literatura}

[1] Filar B.: Analiza wplywu zastosowania różnych technologii udostępniania złóż niekonwencjonalnych na opłacalność ich eksploatacji. Nafta-Gaz 2014, nr 3, s. 143-150.

[2] Joshi S.D.: Horizontal Well Technology. USA, PennWell Books, 1991.

[3] Kasza P.: Efektywne szczelinowanie tupków w Polsce. Nafta-Gaz 2013, nr 11, s. 807-813.

[4] Matyasik I., Słoczyński T.: Niekonwencjonalne złoża gazushale gas. Nafta-Gaz 2010, nr 3, s. 167-177.

[5] Rokosh C.D., Pawlowicz J.G., Berhane H., Anderson S.D.A., Beaton A.P.: What is shale gas? An introduction to shale-gas

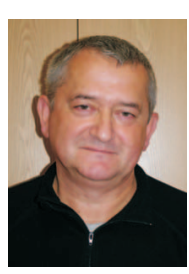

Mgr Mariusz MIZIOŁEK

Starszy specjalista badawczo-techniczny w Zakładzie Podziemnego Magazynowania Gazu.

Instytut Nafty i Gazu - Państwowy Instytut Badawczy

ul. Lubicz 25 A

31-503 Kraków

E-mail: mariusz.miziolek@inig.pl geology in Alberta. Energy Resources Conservation Board / Alberta Geological Survey, Canada 2009.

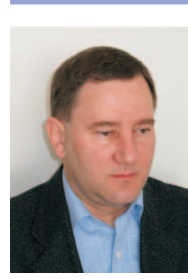

Mgr inż. Bogdan FILAR

Starszy specjalista badawczo-techniczny; kierownik Zakładu Podziemnego Magazynowania Gazu. Instytut Nafty i Gazu - Państwowy Instytut Badawczy

ul. Lubicz 25 A

31-503 Kraków

E-mail:bogdan.filar@inig.pl

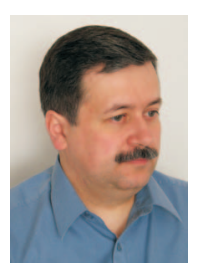

Dr Tadeusz KWILOSZ

Adiunkt w Zakładzie Podziemnego Magazynowania Gazu.

Instytut Nafty i Gazu - Państwowy Instytut Badawczy

ul. Lubicz 25 A

31-503 Kraków

E-mail: tadeusz.kwilosz@inig.pl 